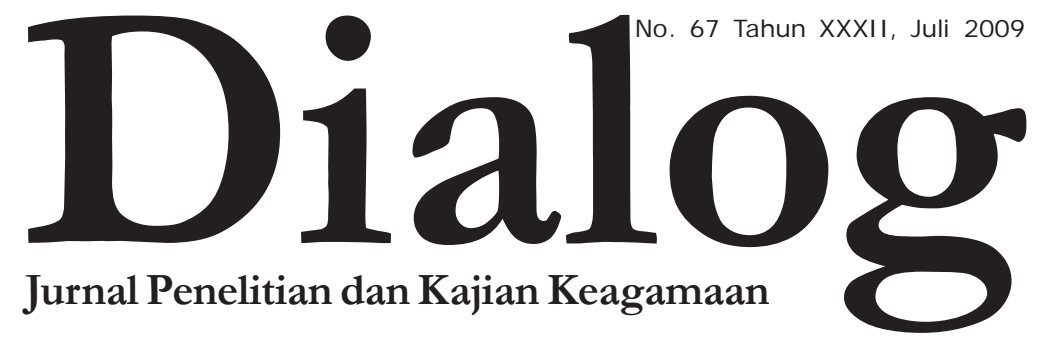

PERBANKAN SYARIAH DI INDONESIA

\begin{tabular}{|l|l|l|l|l|l|}
\hline Jurnal & $\begin{array}{l}\text { Nomor } \\
\text { Dialog }\end{array}$ & $\begin{array}{l}\text { Tahun } \\
\text { XXXII }\end{array}$ & $\begin{array}{l}\text { Halaman } \\
137\end{array}$ & Jakarta & ISSN \\
Juli 2009 & 0126-396X \\
\hline
\end{tabular}




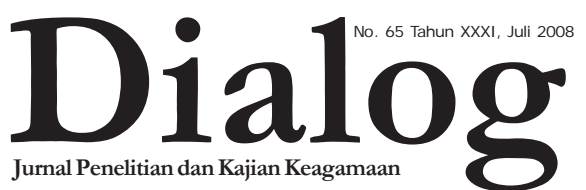

Pemi mpin Umum:

Prof. Dr. H. M. Atho Mudzhar, MA

Redaktur Aht :

Prof. Dr. H. Nasaruddin Umar, MA

Prof. Dr. H. Komarudin Hidayat, MA

Pemimpin Redaksi / Penanggung J awab

Drs. H. Syamsuddin

Waki l Pemi mpin Redaksi

H. Fanani Suprianto, SH., MM

Sekretaris Redaksi

M. Rosyid Fauzi, S.Si.

Dewan Redaksi

Prof. Dr. H. Abdurrahman Mas'ud

Drs. Amin Haedari

Prof. Dr. H. Maidir Harun

Drs. H. Mohammad Shohib, MA

Drs. H. Asmu'i, SH, MM

Chamdi Pamudji, SH., MM

Redaktur Eksekutif

M. Nasir, S.Th.I.

Redaktur Pelaksana

Moh. Rosyid Fauzi, S.Si

M. Nasir, S.Th.I

M. Adlin Sila, M.A

Abbas Jauhari, M.Ag

Admi ni strası

Drs. Dedy Curipno

Sutidjah

Desriyanti Nasution, S.IPI

Drs. H. Sahlani

Alamat Redaksi

Gedung Bayt Alquran Museum Istiqlal Komplek Taman Mini Indonesia Indah

Telp. (021) 87791444-87794982

Website:

www. balitbangdiklat.depag.go.id

Email:

info@depag.web.id

\section{PEIGITIR REDIKSL}

Karakteristik sistem perbankan syariah yang beroperasi berdasarkan prinsip bagi hasil memberikan alternatif sistem perbankan yang saling menguntungkan bagi masyarakat dan bank, serta menonjolkan aspek keadilan dalam bertransaksi, investasi yang beretika, mengedepankan nilai-nilai kebersamaan dan persaudaraan dalam berproduksi, dan menghindari kegiatan spekulatif dalam bertransaksi keuangan. Dengan menyediakan beragam produk serta layanan jasa perbankan yang beragam dengan skema keuangan yang lebih bervariatif, perbankan syariah menjadi alternatif sistem perbankan yang kredibel dan dapat dinikmati oleh seluruh

Jurnal Dialog diterbitkan oleh Badan Litbang dan Diklat Departemen Agama RI, sebagai media informasi dalam rangka mengembangkan penelitian dan kajiaan keagamaan di Indonesia. Dialog berisi tulisan ilmiah dan hasil penelitian dan pengembangan terkait dengan masalah keagamaan. Redaksi mengundang para peneliti agama, pengamat, cendekiawan, intelektual, dan akademisi untuk berdiskusi dan menulis secara bebas serta kreatif demi pengembangan penelitian maupun kajian keagamaan di Indonesia.

2 Dialog No. 67 Tahun XXXII, Juli 2009 
golongan masyarakat Indonesia tanpa terkecuali.

Fungsi Bank Syariah secara garis besar tidak berbeda dengan bank konvensional, yakni sebagai lembaga intermediasi (intermediary institution) yang mengerahkan dana dari masyarakat dan menyalurkan kembali dana-dana tersebut kepada masyarakat yang membutuhkannya dalam bentuk fasilitas pembiayaan. Perbedaan pokoknya terletak dalam jenis keuntungan yang diambil bank dari transaksi-transaksi yang dilakukannya. Bila bank konvensional mendasarkan keuntungannya dari pengambilan bunga, maka Bank Syariah dari apa yang disebut sebagai imbalan, baik berupa jasa (fee-base income) maupun mark-up atau profit margin, serta bagi hasil (loss and profit sharing).

Disamping dilibatkannya Hukum Islam dan pembebasan transaksi dari mekanisme bunga (interest free), posisi unik lainnya dari Bank Syariah dibandingkan dengan bank konvensional adalah diperbolehkannya Bank Syariah melakukan kegiatankegiatan usaha yang bersifat multifinance dan perdagangan (trading). Hal ini berkenaan dengan sifat dasar transaksi Bank Syariah yang merupakan investasi dan jual beli serta sangat beragamnya pelaksanaan pembiayaan yang dapat dilakukan Bank Syariah, seperti pembiayaan dengan prinsip murabahah (jual beli), ijarah (sewa) atau ijarah wa iqtina (sewa beli) (Farouk, 2009), dan lain-lain.
Dalam kajian Jurnal Dialog Edisi ini mencoba menyoroti perkembangan Perbankan Syariah di Indonesia yang beberapa tahun belakangan ini cukup mengalami perkembangan yang signifikan. Sehingga tidak sedikit bank konvensional yang membuka divisi syariah guna berebut nasabah yang kian meminati sistem perbankan syariah. Kajian Jurnal Dialog edisi ini diawali dengan tulisan Dr. Euis Amalia yang mengulas tentang Perbankan Syariah di Indonesia: Kontribusinya Bagi Perekonomian Nasional dan Peran Perguruan Tinggi dalam Rangka Akselerasi. Dilanjutkan dengan tulisan Muhammad Taufiki, M.Ag yang mengupas tentang Aplikasi Konsep Hilah dalam Pengembangan Produk Perbankan Syariah (Analisa terhadap Fatwa tentang Syariah Charge Card).

M. Adlin Sila, MA, peneliti di Badan Litbang dan Diklat Depag mencoba mengulas kemungkinan Bank Syariah Sebagai Bank Bagi Hasil? Ah. Azharuddin Lathif, M.Ag, MH, Dosen Fakultas Syariah dan Hukum UIN Jakarta menghadirkan tulisan tentang Analisis Yuridis Pengenaan Pajak Pertambahan Nilai (Ppn) Dalam Pembiayaan Murabahah di Perbankan Syariah. Sedangkan Prof. Dr. Abd. Rachman Mas'ud Kepala Puslitbang Kehidupan Keagamaan, melalui tulisannya mencoba menyoroti Etika Professional dan Ruh Agama di Awal Millenium. Yulizar D. Sanrego \& Aam S. Rusydiana dosen di Tazkia Institute 
menghadirkan tulisan tentang Peran Perbankan Syariah dalam Mendukung Umkm Pertanian. Kajian ini dilengkapi dengan tulisan Iyoh Masthiyah Peneliti Puslitbang Pendidikan Agama dan Keagamaan Badan Litbang dan Diklat Depag tentang Hak Milik dalam Islam Perspektif Ibn Taymiyah. Kajian dalam Jurnal Dialog edisi ini kian lengkap dengan hadirnya tulisan Yulianti Muhammad yang menganalisis Prospek Perbankan Syariah di Indonesia.

Di samping memuat artikel ilmiah, Jurnal Dialog edisi ini juga memuat laporan hasil penelitian oleh
Dr. Anwar Abbas tentang Ekonomi Islam dan Pemberdayaan Ekonomi Rakyat; Studi Kasus Pemberdayaan Melalui Koperasi Pondok Pesantren Sidogiri Kab. Pasuruan Jawa Timur. Kajian ini diakhiri dengan telaah buku yang mengulas buku karya Drs. Cik Basir, SH, MHI, 2009. Penyelesaian Sengketa Perbankan Syariah di Pengadilan Agama dan Mahkamah Syar'iyah. Semoga kajian yang dihadirkan Jurnal Dialog edisi ini memberikan manfaat yang berarti bagi para pembaca, khususnya dalam kajian Perbankan Syariah di Indonesia. Selamat Membaca!

Redaksi 


\section{DIPTIRISI}

\section{TOPIK}

PERBANKAN SYARIAH DI INDONESIA:

Kontribusinya Bagi Perekonomian Nasional dan

Peran Perguruan Tinggi dalam Rangka Akselerasi

Euis Amalia -6

APLIKASI KONSEP HILAH

DALAM PENGEMBANGAN PRODUK PERBANKAN SYARIAH

(Analisa terhadap Fatwa tentang Syariah Charge Card)

H. Muhammad Taufiki -20

BANK SYARIAH SEBAGAI BANK BAGI HASIL: MUNGKINKAH?

M. Adlin Sila -30

ANALISIS YURIDIS PENGENAAN

PAJAK PERTAMBAHAN NILAI (PPN)

DALAM PEMBIAYAAN

MURABAHAH DI PERBANKAN SYARIAH

Ah. Azharuddin Lathif -52

ETIKA PROFESSIONAL DAN RUH AGAMA

DI AWAL MILLENIUM

Abd. Rachman Mas'ud -69

PERAN PERBANKAN SYARIAH DALAM

MENDUKUNG UMKM PERTANIAN

Yulizar D. Sanrego \& Aam S. Rusydiana -74

HAK MILIK DALAM ISLAM PERSPEKTIF IBN TAYMIYAH

Iyoh Masthiyah --90

PROSPEK PERBANKAN SYARIAH

DI INDONESIA: CERAH ATAU BURAM?

Yulianti Muhammad --101

\section{PENELITIAN}

EKONOMI ISLAM DAN

PEMBERDAYAAN EKONOMI RAKYAT; Studi Kasus Pemberdayaan Melalui

Koperasi Pondok Pesantren Sidogiri Kab. Pasuruan Jawa Timur

Anwar Abbas -117

\section{BOOK REVIEW}

PENYELESAIAN SENGKETA PERBANKAN SYARIAH

(Di Pengadilan Agama dan Mahkamah Syariah)

R. Meilani Dewi - 132 


\title{
Peran Perbankan Syariah Dalam Mendukung UMKM Pertanian
}

\author{
YULIZAR D. SANREGO ${ }^{1}$ \& AAM S. RUSYDIANA 2
}

\begin{abstract}
Abstrak:
Indonesia is an agriculture country. Fourty percent (40\%) of its citizen are concentrated in this sector which has a significant contribution to the national income. However, very much challenge in this sector is waiting for a proper treatment. Critical issue in the process of developing this sector is a financial support. This paper is trying to analyse using expositional descriptive approach the agriculture sector financing opportunity that might be covered by syariah banking industry, challenges as well as its policy steps. It is found that Syariah financing scheme has a positive prospect as an alternative solution for Indonesia agriculture sector problems (i.e. financing service). To encourage and to have sound impelementation, it is expected that syariah banking industry should more courageous and innovative in delivering their financial services and doing collaborative working or channeling with Islamic microfinance institutions. On top of that, Central Bank of Indonesia as a monetary authority, might address intense support to realize such potential growth of agricultural sector.
\end{abstract}

\section{Pendahuluan}

\subsection{Latar BelaKang}

Sangat indah teringat dalam memori kita tentang pembangunan pertanian selama tahun 1970-an dan 1980-an. Menurut Arkam³, kala itu keberhasilan yang ditunjukkan oleh sektor pertanian rata-rata sekitar 3,2\%

\footnotetext{
${ }^{1}$ Kepala Lembaga Penelitian dan Pemberdayaan Masyarakat (LPPM), Sekolah Tinggi Ekonomi Islam (STEI) Tazkia. Jl Raya Darmaga KM7, Bogor 16680. Email: senapatie@yahoo.com

${ }^{2}$ Staf Peneliti LPPM, Sekolah Tinggi Ekonomi Islam (STEI) Tazkia. Email: tasik_pisan@yahoo.com

${ }^{3}$ Arkam Andi Ihsan (2008), Makalah berjudul "Potensi Strategis Pertanian dalam Membangun Perekonomian Indonesia", halaman 3.
}

74 Dialog No. 67 Tahun XXXII, Juli 2009 per tahun untuk pertumbuhan PDB. Swasembada beras dapat dicapai pada tahun 1984, dan telah berhasil memacu pertumbuhan ekonomi pedesaan pada 1980-an. Swasembada beras ini hanya dapat dipertahankan sampai tahun 1993. Produktivitas padi Indonesia adalah yang tertinggi di Asia Tenggara. Upah tenaga kerja pertanian dan harga pupuk terendah di Asia Tenggara, dan oleh karenanya Indonesia memiliki keunggulan kompetitif beras sebagai substitusi impor.

Meskipun swasembada beras tersebut hanya dapat kita rasakan sampai tahun 1993, 'citra positif' sektor pertanian tidak berhenti begitu saja. 
Gema pembangunan pertanian dimulai kembali pada awal era reformasi, mengingat sumbangsih yang besar dari sektor pertanian dalam menopang roda perekonomian pada masa krisis moneter yang melanda sejak pertengahan 1997 utamanya pada upaya stabilisasi kesejahteraan masyarakat menengah ke bawah.

Dalam riset terbaru ADB (Asian Development Bank) dinyatakan bahwa setiap sektor pertanian tumbuh 10 persen maka jumlah orang miskin akan berkurang 1,5-12 persen. Studi ini menunjukkan bahwa pertanian sampai kapan pun harus tetap mendapat perhatian yang besar dari pemerintah dan seluruh pemangku kepentingan. Berikut ini adalah beberapa urgensi sektor pertanian dalam perekonomian Indonesia ${ }^{4}$ :

a) Sektor pertanian merupakan andalan mata pencaharian sebagian besar penduduk/ penyerap terbesar tenaga kerja yakni sekitar 41.2 persen pada 2007,

b) Pertanian berkontribusi besar terhadap PDB yakni sekitar 13.8 persen pada 2007,

c) Merupakan sumber devisa (ekspor) terutama komoditas kelapa sawit dan karet,

d) Hasil dari sektor pertanian menjadi sumber bahan baku industri,

e) Penyedia bahan pangan dan gizi penduduk negara,

f) Pendorong bergeraknya sektorsektor ekonomi riil yang lain,

4 Ashari dan Saptana, 2005, "Prospek Pembiayaan Syariah untuk Sektor Pertanian", Kertas kerja Pusat Analisis Sosial Ekonomi dan Kebijakan Pertanian, Bogor, halaman 8. g) Penyangga perekonomian nasional saat terjadi krisis ekonomi, seperti pengalaman ketika terjadi twin crisis, krisis moneter dan perbankan tahun 1997.

Terkait dengan kontribusi pertanian pada ekonomi nasional di Indonesia, meskipun kontribusinya dalam hal share pada PDB dan penyedia lapangan kerja cenderung menurun, namun pertanian tetap memberikan peran yang signifikan. Pada tahun 2003, pertanian masih menyumbang $15,2 \%$ PDB dan terus mengalami penurunan, tahun 2007 pertanian masih menyumbang 13,8\% PDB. Jika ditinjau dari jumlah tenaga kerja yang diserap, pertanian masih sangat penting kontribusinya, pada tahun 2007, jumlah tenaga kerja yang bekerja di sektor pertanian adalah sekitar $41,2 \%$ dari seluruh angkatan kerja di Indonesia.

Tabel 1.1.

Kontribusi Sektor Ekonomi terhadap PDB dan Tenaga Kerja

\begin{tabular}{|c|c|c|c|c|c|c|c|c|}
\hline \multirow{3}{*}{ Tahun } & \multicolumn{8}{|c|}{ Kontribusi Soldtot Ekonoml ("c) } \\
\hline & \multicolumn{2}{|c|}{ Pertanian } & \multicolumn{2}{|c|}{ Industrt } & \multicolumn{2}{|c|}{ Jasa } & \multicolumn{2}{|c|}{ Pendagangar } \\
\hline & PDB & TK & FDB & TK & PDB & TK & PDB & TK \\
\hline 2003 & 15.2 & 46 & 28 & 11.8 & 181 & 10.3 & 16.2 & 19.2 \\
\hline 2004 & 14.9 & 43 & 28.4 & 12.1 & 18.3 & 10.5 & 16.4 & 19.5 \\
\hline 2005 & 145 & 41.3 & 281 & 12 & 18.4 & 10.3 & 16.8 & 19 \\
\hline 2006 & 16.2 & 60.1 & 27.8 & 11.9 & 18.4 & 11.4 & 16.9 & 19.2 \\
\hline 2007 & 13.8 & 41.2 & 27,4 & $12 / 4$ & 187 & 12 & 17,3 & 20.6 \\
\hline
\end{tabular}

Sumber: Laporan Perekonomian Indonesia, Bank Indonesia (2007)

Seiring dengan adanya peran strategis sektor pertanian dalam meyerap tenaga kerja, menurunkan angka kemiskinan maupun potensinya dalam menyumbang PDB negara, permasalahan yang krusial adalah

Dialog No. 67 Tahun XXXII, Juli 2009 75 
berkaitan dengan akses finansial yang masih minim dimiliki oleh para pelaku di sektor tersebut. Sektor usaha yang didominasi oleh usaha mikro dengan segala keterbatasan dalam memenuhi syarat mendapatkan pembiayaan. Paper ini bertujuan untuk mempelajari peluang pembiayaan sektor pertanian yang mungkin bisa diperankan oleh industri perbankan syariah Indonesia dalam membuka peluang pembiayaan UMKM sektor pertanian. Studi ini menggunakan metode kualitatif eksposisif yang mencoba menggambarkan lebih komprehensif kondisi sektor pertanian di Indonesia serta kemungkinan pembiayaan berskema syariah untuk dijadikan sebagai solusi alternatif.

\section{Tinjauan Pustaka}

2.1 Perspektif Pembangunan Pertanian Sebagaimana telah dipahami bersama oleh berbagai kalangan, pembangunan pertanian memiliki arti yang sangat strategis, tidak hanya bagi negara-negara berkembang, bagi negara maju pun pertanian tetap mendapat perhatian dan perlindungan yang sangat serius (kasus EU, Amerika, Australia, Jepang, dll). Membahas pertanian adalah membahas tentang "kelangsungan hidup". Pertanian adalah penyedia bahan pangan, bahan sandang dan bahkan bahan papan. Selama manusia di dunia masih memerlukan bahan pangan untuk menjamin kelangsungan hidupnya maka pertanian tetap akan memegang peran yang sangat penting. Meskipun dalam kenyataanya, persepsi akan arti penting pertanian kadang-kadang dilupakan oleh banyak orang.

76 Dialog No. 67 Tahun XXXII, Juli 2009
Peluang pengembangan pertanian serta arti penting pertanian adalah adanya fakta bahwa Indonesia memiliki potensi produksi pertanian tropis yang sangat besar dan memiliki potensi pasar pangan yang sangat besar pula yang ditunjukkan oleh pertumbuhan penduduk nasional yang signifikan yaitu 200 juta jiwa di tahun 2000 dan diperkirakan mencapai 400 juta jiwa pada tahun 20405. Potensi pertanian Indonesia dengan segala keterbatasannya sebenarnya memiliki kedudukan yang cukup baik di kancah internasional. Seperti dilansir oleh The Economics dalam The world in figures, Indonesia adalah penghasil biji-bijian nomor 6 di dunia, penghasil beras nomor 3 setelah China dan India, penghasil kopi nomor 4, penghasil coklat nomor 2 setelah Pantai Gading dan Ghana, penghasil lada putih nomor 3 , penghasil karet alam nomor 4, penghasil cengkeh nomor 1 serta penghasil sawit nomor 2 (diprediksi 5 tahun ke depan akan menempati nomor 1 dengan melampaui Malaysia).

Dalam konteks sejarah ekonomi dan pembangunan pertanian di Indonesia, telah terjadi pasang surut kehidupan petani yang menerima dampak kebijakan pada masanya. Secara umum, petani nampaknya selalu berada pada posisi yang lemah dan termarjinalkan oleh berbagai kebijakan yang sering tidak berpihak dan tidak memberikan dampak yang nyata pada perbaikan kualitas hidupnya. Secara umum pembangunan pertanian lebih banyak dinikmati lapisan atas dan

${ }^{5}$ Yudohusodo dalam Subejo, 2006, “Memahami dan Mengkritisi Kebijakan Pembangunan Pertanian di Indonesia", makalah ilmiah pada Temu Nasional Mahasiswa Pertanian Indonesia. 
kurang dinikmati petani gurem yang merupakan bagian terbesar dari jumlah petani. Di samping itu, nasib ekonomi petani Indonesia kian terpuruk karena tidak mendapat perlindungan pemerintah. Hal ini sangat berbeda dengan yang dialami para petani di Amerika, EU, Australia dan Jepang.

Dengan melihat potensi sumber daya yang dimiliki Indonesia, Subejo ${ }^{6}$ mengajukan hipotesis bahwa suatu kebijakan pembangunan pertanian yang baik harus mengandung tiga unsur yaitu ecological security, livelihood security dan food security. Suatu sustainable agriculture adalah suatu sistem pertanian yang mendasarkan dirinya pada pemanfaatan sumber daya alam (lahan, air dan kenearagaman hayati lainnya) secara lestari. Keanekaragaman hayati merupakan kekuatan petani dalam upaya melestarikan ketahanan pangan. Keanekaragaman hayati dapat menjadi sumber alternatif dalam penganekaragaman jenis-jenis tanaman budidaya.

Paradigma pembangunan pertanian baru yang dapat mencapai tujuan tersebut adalah paradigma pembangunan pertanian yang melihat bahwa pembangunan suatu negara adalah pembangunan yang mencerminkan kesejahteraan dari mayoritas penduduk negara itu. Mayoritas penduduk negara-negara sedang berkembang adalah petani. Paradigma pembangunan pertanian baru harus bertujuan untuk lebih menjamin keamanan pangan secara mandiri dan berkelanjutan.

Agar paradigma baru tersebut dapat mencapai tujuannya, dibutuhkan

\footnotetext{
${ }^{6}$ Ibid halaman 13
}

perubahan visi dan kebijaksanaan dari pemerintah dan aparat pelaksana dalam memahami proses-proses yang hakiki dari suatu pembangunan pertanian. Menurut Syamsul Bahari ${ }^{7}$, persoalan pangan tidak hanya berkait dengan konsumsi dan produksi tetapi juga soal daya dukung sektor pertanian yang komprehensif. Ada empat aspek yang menjadi pra-syarat melaksanakan pembangunan pertanian: (1) akses terhadap kepemilikan tanah, (2) akses input dan proses produksi, (3) akses terhadap informasi dan pasar dan (5) akses terhadap kebebasan.

Dari keempat prasyarat tersebut, nampaknya yang belum dilaksanakan secara konsisten adalah membuka akses petani dalam kepemilikan tanah dan membuka ruang kebebasan untuk berorganisasi dan menentukan pilihan sendiri dalam berproduksi. Pemerintah hingga kini selalu menghindari kedua hal itu karena dianggap mempunyai risiko tinggi. Kebijakan pemerintah lebih banyak difokuskan pada produksi dan pasar.

\subsection{Pembiayaan (Kredit) \\ Perbankan Indonesia: \\ FAKTA EMPIRIS}

Selama tahun 2007, ekonomi global berada dalam gejolak yang dipicu oleh berlebihnya likuiditas dunia yang mendorong peningkatan arus modal jangka pendek, kemungkinan contagion effect dari krisis subprime mortgage, serta domino effect dan kecenderungan kenaikan harga minyak. Akibat kondisi tersebut, sebagian pihak kawatir, bahwa target pertumbuhan ekonomi Indonesia akan sulit dicapai. Namun, hingga akhir

\footnotetext{
${ }^{7}$ Kompas edisi 15 Maret 2004.
}

Dialog No. 67 Tahun XXXII, Juli 2009 
triwulan III-2007, kekhawatiran tersebut belum mempengaruhi target pertumbuhan ekonomi Indonesia.

Berdasarkan pengumuman yang dikeluarkan oleh Badan Pusat Statistik (BPS) pada tanggal 15 November 2007 yang lalu, pertumbuhan PDB triwulan III-2007 mencapai 6,5\% (y.o.y) atau meningkat sebesar 3,9\% terhadap triwulan sebelumnya. Apabila pertumbuhan ini dapat dipertahankan hingga akhir tahun, maka target pertumbuhan sebesar 6,3\% (y.o.y) pada tahun 2007, dapat dicapai. Sumber pertumbuhan terbesar pada triwulan III-2007 disumbang oleh sektor pertanian $(1,3 \%)$, industri pengolahan $(1,2 \%)$, serta perdagangan, hotel dan restoran $(1,2 \%)$. Sektor industri pengolahan, masih merupakan penyumbang terbesar PDB tahun 2007. Sektor pertanian berhasil melewati sektor perdagangan, hotel dan restoran sebagai penyumbang kedua terbesar PDB Indonesia. Pertumbuhan yang besar pada sektor pertanian, terutama, ditunjang oleh pertumbuhan yang cukup tinggi pada sub sektor perkebunan $(33,7 \%)$.

Pertumbuhan ekonomi akan optimal apabila stabilitas sistem keuangan dapat terpelihara dengan prospek yang baik. Di Indonesia, perbankan masih mendominasi sektor keuangan. Hal ini menimbulkan tingginya ketergantungan kepada perbankan sebagai sumber pembiayaan pembangunan dan perekonomian. Dengan demikian, apabila perbankan tidak dapat menyalurkan pendanaan kepada sektor riil, maka pengaruh kelambatan pertumbuhan ekonomi menjadi terasa. Kondisi ekonomi global yang tidak menguntungkan tersebut

78 Dialog No. 67 Tahun XXXII, Juli 2009 menurut Gamal ${ }^{8}$ ternyata tidak menghambat penyaluran kredit perbankan Indonesia. Bahkan, pertumbuhan kredit yang diberikan sampai dengan triwulan III-2007 telah mencapai $15,35 \%$ dibandingkan akhir tahun 2006. Pertumbuhan kredit tersebut sudah melebihi pertumbuhan kredit perbankan selama tahun 2006.

Sektor ekonomi yang mengalami pertumbuhan kredit paling besar adalah sektor konstruksi $(32,60 \%)$ diikuti oleh sektor keuangan dan jasa dunia usaha $(25,26 \%)$. Sektor ekonomi lain yang mengalami pertumbuhan kredit cukup tinggi adalah sektor pertambangan $(23,10 \%)$. Akan tetapi, pertumbuhan sektor pertambangan tidak stabil pada tiap triwulan. Pada triwulan II-2007, pertumbuhan sektor ini mencapai $44,80 \%$, namun pada triwulan III pertumbuhan tinggal 23,10\%. Hal ini terjadi, karena sebagian besar kredit yang diberikan untuk sektor ini merupakan kredit modal kerja berjangka sangat pendek. Di samping itu, sektor perdagangan, hotel dan restoran juga mengalami kenaikan cukup tinggi $(21,09 \%)$. Peningkatan kredit perbankan di sektor ini, dipicu oleh peningkatan pengeluaran konsumsi rumah tangga pada PDB Indonesia yang mencapai 5,3\% (y.oy) pada triwulan III-2007 dengan nominal sebesar Rp 644,5 trilyun.

Sektor ekonomi lain (yang merupakan pembiayaan konsumsi) mempunyai pangsa paling besar dalam kredit yang diberikan oleh perbankan nasional $(29,23 \%)$. Pertumbuhan kredit yang diberikan kepada sektor ini masih tetap tinggi $(17,31 \%)$, meskipun tidak

8 Merza Gamal, 2007, “Sebaran Kredit Perbankan dan Pembiayaan Syariah", Paper. 
sebesar tahun 2005 dan sebelumnya yang mencapai di atas 30\% per tahun. Pada sektor produktif terjadi pergeseran pada sektor ekonomi yang memiliki pangsa paling besar dalam kredit yang diberikan. Jika sebelum tahun 2007 yang paling banyak mendapatkan kredit adalah sektor industri pengolahan, maka per triwulan III-2007 sektor perdagangan, hotel dan restoran menjadi sektor produktif yang paling banyak mendapatkan kredit perbankan. Sektor keuangan dan jasa dunia usaha mengalami peningkatan outstanding kredit yang cukup tinggi pada triwulan III-2007 (Rp 98.269 milyar) dibanding tahun 2006 yang masih sebesar Rp 78.455 milyar. Kredit sektor ini, merupakan kredit yang ditujukan kepada lembaga-lembaga pembiayaan yang sebagian besar diteruskan menjadi pembiayaan konsumer di berbagai sub sektor.

Sektor pertanian, meskipun masih mempunyai pangsa yang kecil terhadap total kredit yang diberikan oleh perbankan, secara perlahan meningkat pangsanya dari tahun ke tahun. Sektor pertanian secara tidak diduga oleh banyak pihak, dapat menjadi penyumbang petumbuhan PDB Indonesia terbesar pada triwulan III-2007.

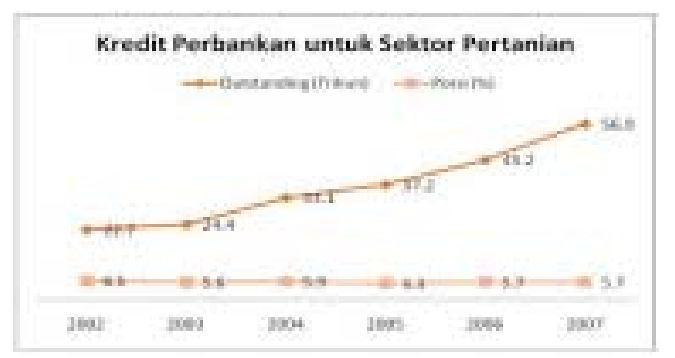

Gambar 3.5.

Kredit Perbankan Komersial untuk Sektor Pertanian
Pada gambar di atas, dapat dilihat bahwa outstanding kredit yang diberikan perbankan komersial nasional dari tahun ke tahun mengalami kenaikan. Pada tahun 2002 yang hanya tercatat $\mathrm{Rp} 22,7$ triliun naik menjadi Rp 33,1 triliun pada 2004, dan mencapai Rp 56,9 triliun pada akhir 2007. Meskipun demikian, porsi persentase kredit sektor pertanian dari keseluruhan kredit yang dikucurkan perbankan nasional masih berada pada kisaran 5 hingga 6 persen setiap tahunnya.

Berdasarkan jenis penggunaan, outstanding kredit yang diberikan perbankan nasional, merupakan kredit modal kerja. Akan tetapi pertumbuhan paling tinggi terjadi pada kredit yang digunakan untuk konsumsi yang mencapai $17,38 \%$ dalam tiga triwulan dibandingkan dengan akhir tahun 2006. Kredit yang diberikan untuk investasi hanya Rp 172,462 milyar (18,87\%) dari Rp 913.960 milyar total outstanding kredit perbankan nasional. Perbankan syariah sebagai bagian perbankan nasional turut berkontribusi dalam sektor keuangan untuk membiayai sektor-sektor ekonomi dalam PDB Indonesia. Pangsa pembiayaan syariah per triwulan III-2007 masih 2,80\% dari total kredit yang diberikan oleh perbankan nasional. Pertumbuhan pembiayaan syariah selama triwulan III2007 masih jauh lebih tinggi daripada pertumbuhan kredit yang diberikan perbankan nasional, yakni $25,16 \%$ dibandingkan akhir tahun 2006.

Dapat dilihat pada gambar berikut ini, setelah mengalami penurunan dari medio tahun 2006 yang sekitar 4,1\% hingga kuartal ketiga tahun 2007 $(2,3 \%)$, pembiayaan yang dilakukan industri perbankan syariah untuk 
sektor pertanian kembali naik menjadi 3,2\% pada Bulan Agustus 2008. Hal ini dicerminkan juga dengan kenaikan outstanding pembiayaan yang mencapai sekitar Rp 1,1 triliun (Agustus 2008) dari awalnya hanya $\operatorname{Rp} 0,6$ triliun pada November 2007.

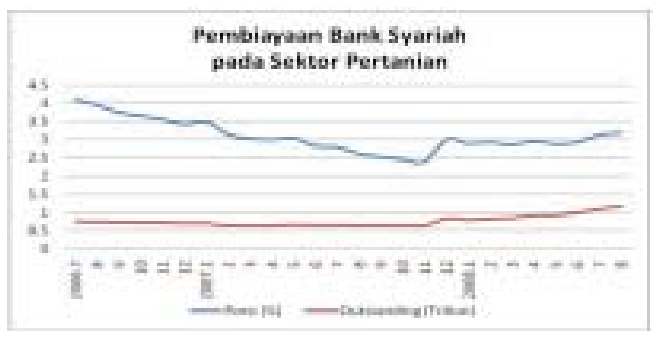

Gambar 3.2.

Pembiayaan Bank Syariah

pada Sektor Pertanian

Sektor produktif, di luar pertanian, meskipun mengalami peningkatan outstanding pembiayaan syariah, namun mengalami penurunan pangsa dibandingkan total pembiayaan yang diberikan. Sektor industri yang menjadi penyumbang PDB hanya mendapat pangsa $4,68 \%$ dari total pembiayaan syariah. Sektor ini mengalami penurunan pangsa secara bertahap sejak tahun 2004. Sedangkan sektor produktif lainnya hanya memperoleh pangsa masing-masing $1,92 \%$ untuk sektor pertambangan, $8,91 \%$ untuk sektor konstruksi, serta $6,12 \%$ untuk sektor transportasi dan komunikasi. Dari data di atas, dapat dilihat bahwa pembiayaan syariah di Indonesia saat ini belum terpola. Jika pada tahun 2004 dan sebelumnya, komposisi pembiayaan yang berkaitan dengan konsumsi dengan sektor produktif masih berimbang, maka saat ini justru komposisi pembiayaan yang

Dialog No. 67 Tahun XXXII, Juli 2009 berkaitan dengan konsumsi semakin jauh meninggalkan sektor produktif.

\subsection{KetidakberpihaKan BanK terhadap Sektor Pertanian}

Keberpihakan bank lewat kredit laksana darah segar, tetapi meskipun demikian yang sering tersaji adalah ketimpangan kucuran kredit. Persentase kredit perbankan untuk perindustrian menghadirkan disparitas yang sangat tajam, yakni mencapai 23,28 persen, sementara untuk pertanian dan perikanan hanya 5,39 persen. Demikian juga dengan penyebaran kredit yang menunjukkan perbedaan yang cukup mencolok, di mana $\mathrm{Rp} 382,87$ triliun disebar di Provinsi DKI yang merupakan 49 persen dari total kredit perbankan nasional. Padahal, pertumbuhan sektor pertaniannya hanya 0,69 persen. Sisanya, sebanyak 51 persen disebar di 32 provinsi, di mana di daerah ini sektor pertanian lebih banyak mendominasi.

Begitu juga kalau ditinjau dari penerima kredit, tampaknya kredit perbankan begitu royal terhadap properti mewah, seperti apartemen. Untuk yang disebut terakhir ini, kredit yang dikucurkan mencapai Rp 33.069 miliar. Bandingkan dengan agrobisnis yang hanya menerima kucuran kredit sebesar Rp 11.329 miliar. Tentu saja hal ini tidak mengalunkan kecemasan seandainya sektor industri dihuni lebih sesak dari pada sektor pertanian. Tetapi, kenyataan sektor pertanian lebih riuh tenaga kerjanya. Pada 2006 ada 42,32 juta yang berteduh di sektor pertanian, meningkat lagi pada 2007, mencapai 42,61 juta jiwa.

Sementara itu, serapan tenaga kerja pada sektor industri pada 2007 
hanya 12,09 juta jiwa, lebih tinggi dari tahun sebelumnya yang hanya 11,58 juta jiwa. Maka, dengan bahasa sederhana, ketika kucuran kredit lebih digelontorkan pada sektor pertanian, tentu dapat bermanfaat lebih banyak. Laju pertumbuhan pertanian tentu dapat didorong lebih kencang. Rasio yang diperankan perbankan sedikit sekali pada sektor pertanian. Pada awal musim tanam kekurangan modal sering menjadi pil pahit yang harus ditelan petani. Di sinilah seolah dosa perbankan, permohonan kredit yang berbelit dan berliku membuat petani harus bersimpuh di kaki para pengijon, tengkulak, bahkan rentenir.

Karena itu, diperlukan akses yang lebih besar untuk pembiayaan bagi petani lewat perbankan. Pihak perbankan diharapkan mempunyai skenario baru yang lebih fokus terhadap sektor pertanian. Menganaktirikan pertanian yang sering diperankan perbankan selama ini dikarenakan sektor ini dianggap mempunyai risiko kegagalan yang sangat tinggi walaupun alasan ini akan mentah bila kita mau melongok Thailand. Begitu mesranya hubungan perbankan dan pertanian di Negara Gajah Putih itu. Negara tersebut menyadari bahwa pertanian dapat dijadikan sebuah jalan untuk menuju kemakmuran ${ }^{9}$. Berbagai elemen membahu untuk mewujudkan sekaligus meruntuhkan sekat yang menghalangi kemajuan di sektor pertanian.

Petinggi yang berkuasa di Thailand menyadari bahwa transformasi ekonomi yang benar ialah dengan memperkuat fondasi yang

${ }^{9}$ Wiji Widodo, L. 2008, “Obesitas Keuntungan Perbankan", Makalah halaman 5. memang mereka yakini bisa bersaing dalam hal tersebut. Dengan kemajuan pertanian yang telah dicapai, maka sedikit demi sedikit masalah krisis ekonomi yang melanda negara tersebut dapat teratasi. Bahkan, sekarang Thailand menjadi salah satu negara agraris yang hasil pertaniannya dapat memenuhi kebutuhan di negara ASEAN. Tak hanya mencukupi, tetapi dapat membanjiri pasar-pasar buah di tanah air. Petani Thailand boleh dibilang tidak punya persoalan dengan bibit unggul baik dari segi kualitas maupun kuantitas. Departemen Pertanian dan juga pengusaha berada di garda paling depan untuk menyediakan bibit yang dibutuhkan para petani. Penelitian untuk mencari varitas unggul telah menjadi keharusan di Thailand. Petani juga tidak harus menunggu dan melalui alur yang rumit untuk mengajukan kredit sebagai tambahan modal. Thailand memiliki Bank for Agriculture and Agricultural Cooperatives (BACC) yang memang khusus menjadi lembaga keuangan untuk sektor pertanian.

Entahlah kemesraan antara perbankan dan pertanian di negara ini kapan akan dihadirkan. Gendutnya perolehan laba dan royalnya kucuran kredit dari perbankan tampaknya belum mampu menghangatkan ruang sektor pertanian dan kubangan kemiskinan pun masih cukup dalam karena 23,61 juta jumlah penduduk miskin dari total 37,17 juta orang itu berada di daerah perdesaan. Umumnya terlibat atau berhubungan dengan sektor pertanian. Bahkan, 72 persen kelompok petani miskin adalah dari bidang pertanian pangan. Maka sulitnya permodalan bagi petani masih subur diperankan

Dialog No. 67 Tahun XXXII, Juli 2009 
oleh para tengkulak dan rentenir dan belum dapat disandarkan pada perbankan nasional. Gemerlapnya kondisi perbankan tahun kemarin dengan lebatnya perolehan laba, moncernya kucuran kredit serta mengelembungnya total aset hanya akan menjadi pigura indah dalam potret kesedihan bangsa.

\section{Islam dan Pertanian}

\subsection{Konsep Islam tentang}

\section{Pembangunan Pertanian}

Menurut Hafidhuddin ${ }^{10}$, terdapat beberapa konsep dan prinsip Islam yang masih sangat relevan dengan kondisi pembangunan pertanian Indonesia saat ini. Pertama, pentingnya keberpihakan pada petani. Ini adalah prinsip yang sangat fundamental karena ternyata berdasarkan kajian sejarah, petani selalu berada pada kondisi yang lebih lemah posisi tawarnya. Ajaran Islam sangat menekankan urgensi keberpihakan kepada masyarakat kecil. Dalam sebuah hadis, Rasulullah SAW bersabda: "Kalian akan ditolong dan diberi rezeki dengan sebab (kalian menolong) kaum dhuafa di antara kalian". Pembelaan dan perlindungan terhadap petani harus menjadi bagian dan prioritas negara. Bagaimana pun, sektor pertanian merupakan sektor yang sangat fundamental karena memiliki keterikatan langsung dengan kebutuhan hidup manusia.

Kedua, penyediaan kebutuhan permodalan dan bantuan pemasaran. Salah satu sebab mengapa Rasulullah membolehkan bai' as-salam adalah karena beliau menyadari bahwa petani sangat bergantung pada permodalan.

${ }^{10}$ Didin Hafidhuddin, 2008, Makalah berjudul "Pertanian dengan Prinsip Syariah" halaman 7.

82 Dialog No. 67 Tahun XXXII, Juli 2009
Karena itu, sudah saatnya skema-skema pembiayaan pertanian berbasis syariah harus terus didorong dan ditingkatkan. Jika perlu, pemerintah menerbitkan sukuk berbasis akad salam sebagai pintu investasi di sektor pertanian.

Ketiga, inovasi dan diversifikasi produk. Ini adalah prinsip yang sangat penting dan mendasar. Ajaran Islam adalah ajaran yang mendorong umatnya untuk selalu berinovasi. Banyak ayat dan hadis yang mengajak umatnya untuk selalu berpikir dan membuat berbagai terobosan baru. Salah satu hal penting yang perlu dilakukan dalam membangun sektor pertanian Indonesia, adalah melalui upaya berkesinambungan dalam menciptakan berbagai inovasi teknologi pertanian. Inovasi juga bisa dalam bentuk menciptakan sistem pengelolaan pertanian yang lebih baik, seperti mengembangkan agrobisnis dan agroindustri sebagai alat untuk meningkatkan value added atau nilai tambah produk pertanian.

Keempat, memanfaatkan sumber daya alam secara optimal dan bijak. Allah SWT telah menegaskan bahwa seluruh isi langit dan bumi diciptakan untuk memenuhi kebutuhan manusia. Karena itu, manusia diperintahkan untuk mengelola segala potensi kekayaan alam ini secara optimal, dengan tetap memerhatikan kelestarian alam dan lingkungan. Dalam konteks mengelola segala potensi kekayaan alam (baca; lahan pertanian), pembahasan berikut akan memaparkan prinsip investasi atas lahan pertanian dengan merujuk kepada kajian fiqh muamalah. 


\subsection{Produk Pembiayaan Syariah \\ untuk Pertanian}

Terdapat beberapa skema syariah yang memungkinkan dalam realisasi pembiayaan sektor pertanian, di antaranya adalah mudharabah, musyarakah, muzara'ah, mukhabarah, musaqah, bai' murabahah, istishna, salam dan rahn. Paper ini hanya mengkhususkan untuk membahas muzara'ah, mukhabarah dan musaqah yang sangat terkait dengan model investasi kerja sama (syirkah) antara shohibul mal (pemilik modal) dan mudharib (pengelola) antitesa dari konsep riba yang memiliki karakteristik zero sum game.

Muzara'ah, mukhabarah dan musaqah merupakan bentuk kerja sama atas lahan pertanian di mana para pihak yang terlibat baik pemilik modal maupun pengelola sama-sama memiliki peranan masing-masing. Keuntungan atau kerugian yang akan diraih sebagai buah dari kerja sama tersebut tergantung pada investasi yang mereka keluarkan dalam kerja sama tersebut. Pada gilirannya, perbedaan peran tersebut akan membawa konsekwensi pada rasio pembagian keuntungan ataupun kerugian yang akan ditanggung bersama. Kerja sama dalam Islam didasarkan kepada bentuk fungsi dan tugas para pihak yang terlibat berdasarkan jenis investasi yang mereka sertakan. Syirkah atau musyarakah merupakan bentuk kerjasama dimana fungsi dan jenis investasi ditanggung bersama sementara mudharabah merupakan bentuk kerja sama di mana fungsi dan jenis investasi dibedakan pertanggungjawabannya oleh kedua belah pihak. Dengan merujuk kepada kedua prinsip inilah maka bentuk kerjasama atas lahan pertanian dapat berbentuk syirkah atau mudharabah.

Dalam pengelolaan lahan pertanian, maka sesungguhnya fungsifungsi kerja sama dapat dibedakan dalam fungsi mendasar yakni pengadaan lahan pertanian yang siap tanam (bukan lahan mati), pekerjaan penanaman dan pemeliharaan serta pemanenan. Sedangkan dari segi bentuk investasi maka ada yang bersifat modal berkesinambungan (yang dapat digunakan berulang-berulang dan zat serta manfaatnya tidak hilang dalam aktifitas pertanian) seperti peralatan pertanian, mesin dan lainnya. Ada juga yang berbentuk modal habis (yang digunakan sebagai biaya yang habis dalam pertanian) seperti bibit, pupuk dan lainnya ${ }^{11}$. Perbedaan tanggung jawab atas hal-hal di ataslah yang sesungguhnya membedakan bentuk transaksi muzara'ah, mukhabarah dan musaqah.

Dalam konteks perjanjian muzara'ah, pemilik lahan bertanggungjawab atas penyediaan lahan yang siap ditanami. Sedangkan pengelola bertanggung jawab atas penyediaan alat-alat pertanian, bibit dan pupuk, teknologi, proses penanaman, pemeliharaan hingga pemanenan. Dengan demikian dapat dipahami bahwa tuan tanah tidak dapat mempertahankan tanah hanya dengan meminta orang lain mengelolanya dan ia mendapatkan keuntungan dari hasil panen tanpa menanggung risiko

${ }^{11}$ Bambang Hermanto, 2007, “Agro Investasi dalam Perspektif Ekonomi Islam dan Konvensional (Sebuah Pencerahan terhadap Konsep Fiqh Mu'amalah). " Jurnal Hukum dan HAM, Vol 4 No.2, UIN Sultan Syariah Kasim Riau. 
apapun. Namun, ia wajib menjaga produktifitasnya dengan mempertahankan kesuburan dan perawatan lahan. Dalam perjanjian kerjasama tersebut, mengingat tidak banyaknya peran dan tanggung jawab yang dimilikinya maka sangat wajar bila ia mendapatkan lebih sedikit rasio bagi hasil dibanding pengelola. Dan bila kerja sama tersebut menderita kerugian seperti dalam hal kegagalan panen, maka ia cukup menanggung risiko dengan tidak mendapatkan hasil produktifitas tanahnya.

Sementara itu pemilik lahan dengan begitu banyak peran yang ia miliki, maka wajar jika ia mendapatkan rasio pembagian yang lebih dari hasil panen mengingat besarnya risiko yang ia akan alami bila terjadi kegagalan dalam usaha tersebut. Bentuk musaqah ini menunjukkan perhatian Islam dalam menjaga hak kepemilikan individu dan distribusi lapangan pekerjaan yang dapat menyerap tenaga non profesional untuk tetap dapat memberikan kontribusinya bagi lahan pertanian. Ilustrasi di bawah menjelaskan bagaimana hubungan peran dan tanggung jawab masing-masing pihak serta kemungkinan rasio pembagian hasil panen ${ }^{12}$ :

\begin{tabular}{|c|c|c|c|c|c|c|}
\hline $\begin{array}{l}\text { Bertuk } \\
\text { Kefiama }\end{array}$ & $\begin{array}{l}\text { Permedism lahor } \\
\text { Sap Tanzen }\end{array}$ & $\begin{array}{l}\text { Bibit: } \\
\text { Pupat }\end{array}$ & $\begin{array}{l}\text { Alnt-sint } \\
\text { Putretian }\end{array}$ & Pearelihuran & \multicolumn{2}{|c|}{$\begin{array}{c}\text { Rasoo } \\
\text { Bag Hasil" }\end{array}$} \\
\hline & & & & & $\theta$ & 6 \\
\hline Damarah & 6 & 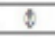 & 4 & 8 & S9, & 754 \\
\hline $\begin{array}{l}\text { Malhabia } \\
\text { h }\end{array}$ & 8 & 5 & $\pi$ & 8 & $5 \%$ & $\mathrm{SO}_{6}$ \\
\hline Masagah & 6 & $\theta$ & $\theta$ & 8 & 794 & 250 \\
\hline
\end{tabular}

Keterangan:

(C): Tanggung jawab pemilik lahan pertanian

(B): Tanggung jawab pengelola lahan pertanian

* : Rasio ini merupakan contoh yang dapat disesuaikan kesepakatan selama tidak merugikan satu sama lain

${ }^{12}$ Ibid halaman 15.

84 Dialog No. 67 Tahun XXXII, Juli 2009
Berdasarkan ilustrasi tersebut maka dapat dipahami bahwa semakin besar peran dan tanggung jawab yang dimiliki oleh tuan tanah atau pengelola lahan semakin besar risiko yang mereka maka semakin besar kemungkinan rasio bagi hasil yang berhak mereka peroleh. Hal ini juga terjadi dalam ekonomi konvensional di mana keuntungan investasi bergantung dari risiko yang dipertaruhkan dari bentuk investasi itu sendiri. Investasi dengan keuntungan tetap lebih sedikit keuntungaan dibanding dengan sistem investasi dengan sistem kredit karena menanggung risiko kredit macet. Investasi dengan penyertaan modal bahkan bisa mendapat keuntungan hingga empat kali lipat dibanding sistem kredit karena menanggung risiko kerugian usaha. Dengan paradigma mendapatkan untung dan risiko kerugian seperti ini maka sesungguhnya sistem kerja sama atas lahan pertanian menurut Islam dapat beradaptasi dengan tradisi ekonomi kontemporer.

Dari beberapa bentuk model kerjasama tersebut, terlihat bahwa dalam perspektif syariah antara sektor usaha (riil) dan keuangan (moneter) harus saling berkaitan, yang amat berbeda dengan praktik ekonomi konvensional. Di dalam ekonomi konvensional kapitalis, sektor moneter cenderung bergerak lebih cepat dan over expansive sehingga apa yang terjadi di sektor moneter tidak mencerminkan fakta riil dalam ekonomi. Permasalahan di lembaga keuangan syariah bukan lagi terletak bagaimana upaya untuk menyeimbangkan antara sektor keuangan dan sektor riil, tetapi permasalahannya terletak pada sejauh 
mana peran lembaga keuangan syariah dalam mendorong pertumbuh-an sektor riil. Berbeda dengan lembaga keuangan konvensional, lembaga keuangan syariah menutup kemungkinan terjadinya decoupling antara sektor keuangan dan sektor riil sebagai karakteristiknya.

Terkait dengan kemampuan sistem kerjasama yang dapat beradaptasi dengan tradisi ekonomi kontemporer, ada penelitian yang mencoba untuk memastikan bahwa pembiayaan syariah memiliki prospek positif pada sektor pertanian. Ashari dan Saptana ${ }^{13}$ mengatakan bahwa pelaksanaan pembiayaan syariah untuk usaha bidang pertanian di pedesaan memiliki prospek positif. Hal ini dilandasi oleh: (a) karakteristik pembiayaan syariah sesuai dengan kondisi bisnis pertanian, (b) beberapa skim pembiayaan syariah sudah jauhjauh hari dipraktikkan masyarakat petani, bahkan telah melembaga, (c) luasnya cakupan bidang usaha pertanian, (d) mengandung nilai-nilai universal, (e) petani memiliki kepatuhan yang tinggi terhadap akad perjanjian, (f) adanya komitmen yang tinggi dari perbankan syariah untuk UMKM, serta (g) usaha di sektor pertanian termasuk kegiatan bisnis riil yang relevan dengan misi lembaga pembiayaan syariah. Beberapa langkah kebijakan operasional yang diperlukan menurut penulis adalah (1) membedah konsep teoritis ke dalam konsep yang aplikatif sehingga mudah diimplementasikan, (2) memantapkan upaya sosialisasi

13 Ashari dan Saptana, 2005, “Prospek Pembiayaan Syariah untuk Sektor Pertanian", Kertas kerja Pusat Analisis Sosial Ekonomi dan Kebijakan Pertanian, Bogor, halaman 17. pembiayaan syariah ke masyarakat petani dan pejabat publik yang menangani sektor pertanian, (3) meningkatkan pemahaman SDM baik di tingkat pengusaha pertanian, pelaku pembiayaan syariah maupun policy maker terhadap prinsip pembiayaan syariah, (4) menyusun peta usaha pertanian yang layak dibiayai dengan pola syariah, (5) penentuan sasaran pembiayaan yang tepat, (6) perumusan skim yang aplikatif dengan prosedur yang sederhana, (7) membangun sistem insentif dan penalti yang tegas, dan (8) menjamin adanya transparansi dan akuntabilitas dalam transaksi dan pengelolaan dananya, serta (9) adanya dukungan peraturan hukum baik di tingkat daerah sebagai unit otonom maupun di tingkat pusat.

Pusat Analisis Sosial Ekonomi dan Kebijakan Pertanian bekerja sama dengan Bank Indonesia Bandung melakukan penelitian tentang Potensi Pembiayaan Syariah untuk Sektor Pertanian Padi dan Palawija di Jawa Barat ${ }^{14}$. Hasil penelitiannya di dapat bahwa pola pembiayaan syariah sangat prospektif untuk diimplementasikan di sektor pertanian. Hal ini didukung dengan karakteristik dari perbankan syariah maupun sifat sektor dan pelaku usaha pertanian yang bisa saling bersinergi. Di antara karakteristik perbankan syariah yang kondusif untuk sektor pertanian adalah (1) spirit pembiayaan syariah sesuai dengan bisnis pertanian, (2) komitmen yang kuat untuk pembiayaan UMKM, (3)

${ }^{14}$ Pusat Analisis Sosial Ekonomi dan Kebijakan Pertanian, Badan Penelitian dan Pengembangan Pertanian, 2007, "Potensi Pembiayaan Syariah untuk Sektor Pertanian Padi dan Palawija di Jawa Barat", Kertas kerja halaman 17. 
Nilai FDR yang relatif tinggi, dan (4) sifat usaha yang universal. Sementara sifat usaha dan pelaku sektor pertanian yang kondusif untuk implementasi pembiayaan syariah adalah: (1) Pola pembiayaan syariah sudah dipraktikkan petani, (2) luasnya cakupan usaha pertanian, (3) karakter pelaku usaha pertanian yang relatif baik dan adanya ikatan emosional, (4) bisnis pertanian terjamin kontinuitasnya, (5) peluang bekerja sama pembiayaan dengan kelembagaan petani, serta (6) ada peluang berpartisipasi dalam kredit program.

Terkait dengan riset peran lembaga keuangan mikro (LKM) sebagai lembaga seperti bank dalam memberikan akses finansial untuk sektor pertanian, Survey Bank Indonesia yang dilakukan oleh tim PPSK tahun 2007 menunjukkan bahwa ada tiga faktor penyebab LKM enggan menyalurkan pembiayaannya untuk sektor tersebut. Pertama, Mismatch dana. LKM tidak memiliki sumber dana jangka panjang (tiga bulan) yang sesuai dengan kebutuhan pembiayaan nasabah pertanian. Bagi LKM, tiga bulan merupakan masa yang relatif panjang dan lama untuk mendapatkan kembali dana yang digulirkan. Tentunya, dana tersebut akan kembali kepada LKM pada saat panen tiba (yarnen). Pada masa tiga bulan inilah LKM merasa tidak memiliki kesempatan untuk menggulirkan kembali dananya yang memang terbatas.

Kedua, Risiko usaha. Masalah ini sangat berkaitan erat dengan sifat usaha pertanian itu sendiri yang memang memiliki risiko yang tinggi. Untuk masalah ini LKM merasa bahwa jika melakukan pembiayaan untuk sektor ini, disamping waktunya lama, juga berisiko untuk tidak mendapatkan keuntungan sama sekali. Risiko dalam hal ini lebih disebabkan oleh pertimbangan alam.

Ketiga, Pemahaman LKM tentang feasibility study yang berkaitan langsung dengan usaha pertanian dan kemampuan teknis lainnya seperti manajemen, produksi dan marketing. Untuk poin ini sumber daya manusia LKM belum memiliki kemampuan khusus dalam membaca feasibility pada usaha pertanian yang layak diberikan pembiayaan. Bantuan dana (financial assistance) memang penting tetapi belum cukup. Kemampuan dalam mengaplikasikan FS dan teknis lainnya untuk usaha-usaha pertanian masih sangat langka di lingkungan LKM. Permasalahan-permasalahan inilah yang seharusnya menjadi titik tolak bagaimana memaksimalkan sinergi antara bank dan peran LKM sebagai lembaga non bank dalam memberikan pembiayaan terhadap usaha-usaha sektor pertanian.

Potensi perbankan dari sisi pelayanan finansial berikut potensi lembaga keuangan mikro yang "dekat" dengan usaha-usaha sektor pertanian yang mayoritasnya tergolong usaha mikro, maka salah satu faktor kunci adalah perlunya dibuat model kemitraan usaha yang terintegrasi antara pelaku usaha pertanian dan pihak perbankan termasuk peran strategis LKM. Pertama, permasalahan mismatch dana yang terjadi bisa dicari jalan keluarnya dengan channeling strategy yang bisa dilakukan dengan bank umum atau dana bergulir dari pemerintah. Strategi inilah yang bisa dilakukan oleh LKM ketika mengalami 
kekurangan dana khususnya dana nasabah LKM itu sendiri. Dana tersebut bisa dikhususkan untuk pola-pola pembiayaan di sektor pertanian. Riset dan Pilot Project Skims Pembiayaan Usaha Tani Pola Syari'ah, misalnya pengembangan KUT Pola Syari'ah dengan skim salam paralel dengan melibatkan BULOG atau perusahaan besar (grosir). Bisa juga skim pembiayaan dengan cost murah yang bersumber dari IDB (Islamic Development Bank)

Pada poin ini pula penulis ingin memastikan bahwa dana-dana yang berasal dari pemerintah betul-betul disesuaikan dengan prioritas kebutuhan dan usaha yang digeluti masyarakat. Hal ini sangat penting karena juga akan menyangkut dengan visi pembangunan pemerintah pusat maupun pemerintah daerah. Dengan potensi yang sangat besar di sektor usaha pertaninan ini, seharusnya pemerintah memiliki visi pembangunan yang jelas untuk sektor ini. Kebijakan integratif mutlak diperlukan.

Kedua, permasalahan risiko pembiayaan di sektor pertanian, selain yang telah dilakukan oleh pemerintah, bisa dilakukan dengan melakukan inisiasi mikro takaful (micro insurance) yang bisa memitigasi risiko pembiyaan terhadap sektor pertanian. Tentunya dengan keberadaan mikro takaful ini diharapkan akan mendukung LKM dalam menjalankan aktivitas dan kegiatannya. Selain itu juga bisa memaksimalkan peran lembaga underwriting sebagai lembaga pengawas untuk menjaga risiko dana yang disalurkan kepada usaha mikro Kecil (UMK).

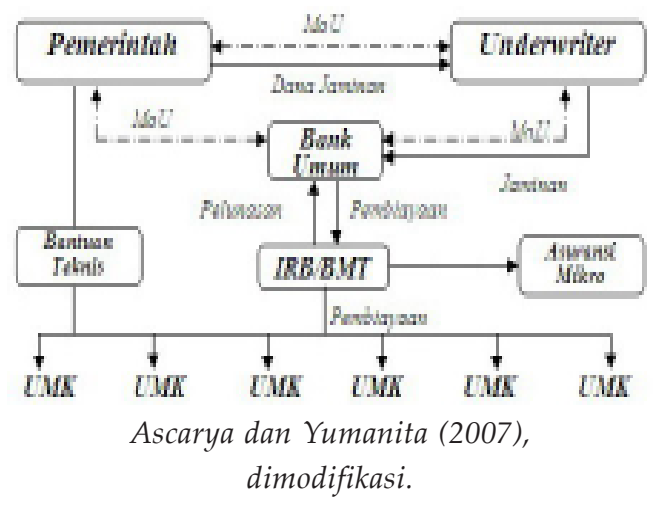

Ketiga, permasalahan kemampuan SDM LKM maupun UMK dalam mengaplikasikan feasibility study dan bentuk teknis lainnya dalam hal pertanian bisa di-upgrade dengan bimbingan atau bantuan teknis dengan menggunakan fasilitas pemerintah. Kemampuan teknis tersebut tentunya akan memberikan bekal bagi para pelaku keuangan mikro khususnya di sektor pertanian agar lebih profesional dan cerdas dalam menjalankan usahanya. Yang tidak kalah penting adalah peran dari LKM sendiri yang secara inovatif meramu pola-pola pembiayaan yang disesuaikan dengan kebutuhan masyarakat di mana LKM itu beroperasi. Kemampuan untuk melakukan product development menjadi hal yang mutlak diperlukan. Adalah tidak bijaksana jika pelaku LKM malah mengalihkan usaha nasabah dari pertanian menjadi usaha perdagangan dengan dalih berisiko dan masa returnya terlampau lama.

Last but not least, wacana untuk menghadirkan bank syariah pertanian menjadi suatu hal yang perlu adanya dalam rangka mempertegas peran perbankan syariah dalam mendorong pembiayaan sektor pertanian 
sebagaimana Thailand yang memiliki Bank for Agriculture and Agricultural Cooperatives (BACC) yang memang khusus menjadi lembaga keuangan untuk sektor pertanian. Di sini juga perlu dipertegas oleh pemerintah mengenai visi pembangunan yang memang seharusnya berbasis pertanian sesuai dengan karakter sumber daya alam Indonesia. Untuk lebih mendorong peran bank syariah terhadap pembiayaan sektor pertanian, pemerintah bisa menghadirkan usaha unit syariah di Bank Rakyat Indonesia (BRI) yang sudah ada. Hal ini menjadi sangat strategis dengan jaringan yang sudah dimiliki oleh BRI. Perlu juga bagi Bank Indonesia sebagai otoritas moneter untuk "memaksa" pelaku perbankan syariah untuk memaksimalkan pembiayaan dengan skema kerja sama, khususnya dalam bidang pertanian. Tentunya upaya tersebut harus didukung penuh dengan memberikan insentif-insentif atau kelonggaran peraturan yang tidak memberatkan bank syariah dalam proses pembiayaan tersebut.

\section{Kesimpulan}

Permasalahan di lembaga keuangan syariah bukan lagi terletak bagaimana upaya untuk menyeimbangkan antara sektor keuangan dan sektor riil, tetapi permasalahannya terletak pada sejauh mana peran lembaga keuangan syariah dalam mendorong pertumbuhan sektor riil. Berbeda dengan lembaga keuangan konvensional, lembaga keuangan syariah menutup kemungkinan terjadinya decoupling antara sektor keuangan dan sektor riil sebagai karakteristiknya. Kemampuan berinovasi, selain yang sudah ada dalam literatur fiqh muamalah, dalam menjawab kebutuhan masyarakat dalam memberikan akses finansial menjadi keniscayaan khususnya di sektor pertanian yang menjadi potret kemiskinan sekaligus potensi untuk meningkatkan pertumbuhan ekonomi Indonesia.

Pihak perbankan syariah bisa mendanai petani dari hulu sampai hilir dan masing-masing pelaku pertanian ini bisa dibangun kemitraan dengan berbagai bentuknya. Permasalahan risiko pembiayaan di sektor pertanian, selain yang telah dilakukan oleh pemerintah, bisa dilakukan dengan melakukan inisiasi mikro takaful (micro insurance) yang bisa memitigasi risiko pembiyaan terhadap sektor pertanian. Wacana untuk menghadirkan bank syariah pertanian menjadi suatu hal perlu adanya dalam rangka mempertegas peran perbankan syariah dalam mendorong pembiayaan sektor pertanian sebagaimana Thailand yang memiliki Bank for Agriculture and Agricultural Cooperatives (BACC) yang memang khusus menjadi lembaga keuangan untuk sektor pertanian. Hal ini terkait dengan visi pembangunan pemerintah yang seharusnya berbasis sektor pertanian sesuai dengan karakter sumber daya alam Indonesia.

Untuk lebih mendorong lagi peran bank syariah terhadap pembiayaan terhadap sektor pertanian, pemerintah bisa menghadirkan usaha unit syariah di Bank Rakyat Indonesia (BRI) yang sudah ada. Hal ini menjadi sangat strategis dengan jaringan yang sudah dimiliki oleh BRI. Perlu juga bagi Bank Indonesia sebagai otoritas moneter "memaksa" pelaku perbankan syariah untuk memaksimalkan 
pembiayaan dengan skema kerjasama khususnya dalam bidang pertanian. Tentunya upaya tersebut harus didukung penuh dengan memberikan insentif-insentif atau kelonggaran peraturan yang tidak memberatkan bank syariah dalam proses pembiayaan tersebut. Mudah-mudahan usahausaha mikro yang berbasis pertanian bisa diperlakukan lebih oleh pemerintah melalui peran industri perbankannya sehingga berdampak pada ketahanan pangan Indonesia yang kuat dan murah.[]
Andi Ihsan, Arkam, 2008, "Potensi Strategis Pertanian dalam Membangun Perekonomian Indonesia", Makalah.

Ascarya, 2006, Akad dan Produk Bank Syariah: Konsep dan Praktek di Beberapa Negara, Jakarta: Bank Indonesia.

Ascarya dan Yumanita, Diana, 2007, "The Profile of MSMEs in Indonesia and The Strategy to enhance Islamic Financial Services Through BMT. Proceedings of the $2^{\text {nd }}$ Conference 2007 (iECONS2007) Faculty of Economics and Muamalat. Islamic Science University of Malaysia.

Ashari dan Saptana, 2005, "Prospek Pembiayaan Syariah untuk Sektor Pertanian", Paper, Pusat Analisis Sosial Ekonomi dan Kebijakan Pertanian. Bogor.

Gamal, Merza, 2007, “Sebaran Kredit Perbankan dan Pembiayaan Syariah", Paper.

Hafidhuddin, Didin, 2008, "Pertanian dengan Prinsip Syariah", Makalah.
Hermanto, Bambang, 2007, Agro investasi dalam Perspektif Ekonomi Islam dan Konvensional (Sebuah Pencerahan terhadap Konsep Fiqh Mu'amalah). Jurnal Hukum dan HAM, Vol 4 No.2, UIN Sultan Syarih Kasim Riau.

Laporan Perekonomian Indonesia Tahun 2007. Bank Indonesia.

Laporan Perekonomian Indonesia Tahun 2006. Bank Indonesia.

Pusat Analisis Sosial Ekonomi dan Kebijakan Pertanian, Badan Penelitian dan Pengembangan Pertanian, 2007, "Potensi Pembiayaan Syariah untuk Sektor Pertanian Padi dan Palawija di Jawa Barat", Paper.

Subejo, 2006, "Memahami dan Mengkritisi Kebijakan Pembangunan Pertanian di Indonesia", makalah ilmiah pada Temu Nasional Mahasiswa Pertanian Indonesia.

Widodo, L. Wiji, 2008, “Obesitas Keuntungan Perbankan", Makalah.

Dialog No. 67 Tahun XXXII, Juli 2009 